\title{
Brexit and the Poverty of Popular Democracy in Great Britain: An Analytical Perspective
}

\author{
L. Andy Afinotan ${ }^{1}$ \\ ${ }^{1}$ Department of Political Science, Joseph Ayo Babalola University, Ikeji Arakeji, Osun State, Nigeria \\ Correspondence: L. Andy Afinotan (Ph.D), Department of Political Science, Joseph Ayo Babalola University, \\ Ikeji Arakeji, Osun State, Nigeria.
}

Received: October 19, 2016

Accepted: October 31, 2016

Online Published: March 28, 2017

doi:10.20849/ajsss.v2i1.134

URL: https://doi.org/10.20849/ajsss.v2i1.134

\begin{abstract}
In the contemporary international system, the trend towards collective security through regional integration for economic and political stability is unmistakable. The European Union, often touted as the quintessential example of a stable and secure regional economic alliance was developed by the contiguous countries of Western Europe for fundamentally strategic reasons. It was basically informed inter alia, by the need to prevent a re-occurrence of war between Germany and France, the two belligerents that dragged the entire world into war twice in one century. Bringing the two countries together in a cooperative prosperity circle, in concert with other European countries, is considered to be a useful means to economic and political stability in the region. The decision of Britain to exit the Union via a domestic referendum therefore, promises to have severe repercussions, not only for the Union, but more fundamentally for Britain itself. Making use of Library Research and content analysis methodologies in an explanatory, historical, and qualitative analytical perspective, the paper examined the roots of the Brexit narrative, and within that context, analysed the plausible consequences of Britain's exit from the Union. The paper concluded that not only will Europe and indeed Africa be hurt by it through the consequences of a possible domino effect on regional organisations and separatist groups worldwide, but also in its reactionary implications, is bound to take Europe back a couple of steps.
\end{abstract}

Keywords: Brexit, European Union, domino effect, regional organisations, referendum, leadership personality

\section{Introduction}

The bubbling trend of globalization has earned the world the rubric of a global village whereby, sovereign states are uniting to jointly tackle issues that are ubiquitous, yet hardly tractable to individual nation-states. Thus, in the wake of the increasing interpenetration and interdependence of the basic constituents of the global arena, socio-political and economic, integration is becoming an unavoidable necessity in the international system. This development came to the fore especially during the period of the decline of the "war eras" which made states gradually come to recognise the unavoidable need to pool resources and concessions together for the overall benefit of their distinct political systems. This has made the concept of regional integration a major buzz-word and also, a substantial theme in the international system in contemporary times. It broadly captures the processes whereby states voluntarily decide and agree to cooperate politically, economically and strategically in order to achieve common developmental goals, jointly tackle economic problems, and (by implication), forming a strong regional pool to boost the power of the region in international relations.

The formation of such regional integration are mostly organised under regional supranational organisations, which rules becomes binding on member states. The shifting of attention to a more cooperative means of socio-political and economic relations is hinged on the premise that, through the reduction of tariff rates, promotion of free trade, encouraging free movement of human and non-human resources, linking local market to regional market and through stronger ties, independent nations can effectively boost their capacity for actualizing their national interests. Supporting this position, the Asian Development Bank, stated that the overall aim why nations decide to cooperate under the regional bloc is to "boost prosperity and reduce poverty and inequality" (ADB, 2013). Accordingly, the body opines that regional integration is one way countries achieve national interest -only in concert with others" and thus avail themselves of the opportunities provided by an expanded regional market. In recognition of this fact, Peters-Berries argues that, the concept of Regional integration appealed to many for one simple reason; This laid in the fact that "it promised to increase the wealth and 
well-being not just of one, but of a number of countries at a rate greater than just the sums of the development of the participating countries' economies" (Peters-Berries, 2010; 11).

The European Union thus became a reflection of an ideal socio-political and economic supranational regional organisation for other regions to emulate. In a world, where the advantages of regional integration is becoming an empirical fact rather than a myth, and the European Union becoming a symbol of excellence worthy of emulation by all other regional Blocs, Britain, conducted a referendum to exit the European Union and opted for isolation in a largely culturally homogeneous regional community. This foreign policy decision raises certain fundamental assumptions: one, that British leaders and citizens are totally informed about the evolving nature of international politics and the place of regional integration therein. Two, that the leaders and the citizens are adequately informed on the implications of a Brexit decision and have very strong belief in their Country's capacity for independent existence and survival afterwards. Based on these assumptions, the paper seeks to interrogate the effectiveness, relevance and significance of the notion of popular democracy in the formulation of decisive and strategic foreign policy options that are crucial to the existence of a state, within the context of the Brexit narrative.

Consequently, the paper is divided into six sections. The first section introduces the study, while the second section puts the theoretical issues in proper perspective. The third examines the evolution of the European Union, and its aims and objectives. The fourth renders the Brexit Narrative and interrogates the doctrine of popular democracy in connection with the Brexit account. The fifth section bridges the gap between theory and actuality. The last section concludes the essay.

\section{Conceptual Framework}

Our preferred conceptual framework for analysis of this problematic is the Leadership Personality Model.

\subsection{The Leadership Personality Model}

With the emergence of the behavioural persuasion in the fields of Political Science and International Relations, literatures have generally acknowledged the centrality of the role of leaders in shaping a direction for either the rise or the fall of nations in international politics. Behaviourism introduced two major elements in the study of politics; the first element emphasizes the political behaviour of individuals as the central and crucial unit of political analysis and the basic building block of political science and the other introduced scientism into political analysis (Omotosho, 2007).

Thus the introduction of the leadership personality model into the study of political analysis is not out of place. The leadership personality model borrows largely from the field of psychology, the model acknowledges that, all nations irrespective of status, position or capacity are guided and administered by individuals designated as the leader of such entity. However, the model moves beyond the ordinary focus on leaders to interrogate, the various factors and motivations that influence the decisions of leaders. In this regard, the personality of the leader is identified as an inevitable element that can be used as an analytical framework for understanding the 'why' of decisions made by the leaders. That is not to mean that the personality traits of the leader alone is what accounts for the decisions of leaders, in this regard, Afinotan and Agagu (2008) argue that it is not to be assumed that "various actors or leaders necessarily choose one model or the other and then make their decisions... Rather, we perceive from observation of the processes the specific models that best describes the method of decision making exhibited by the actors".

Breuning (2007) posits that focus on the personality traits of leaders is often stirred by questions such as; what sort of leader will this personality make? What kind of policy decisions can be expected from a specific leader?

While reviewing the imperatives of the leadership personality model as a tool of analysis in political science, Afinotan and Agagu in their work "Leadership Personality Model as a Tool of Political Analysis" rightly argue that, in the contemporary world, where the executive elites of the state hold in their hands the instruments of war and peace, they wield enormous control over the socio-political and economic welfare of all and sundry within the state. In an era where the weal and woe of whole populations, rest in the hands of a few, the attitudinal predispositions and temperaments of these selected few who are "decision makers are often of the utmost significance if not pivotal to the decision making process itself" (Afinotan and Agagu; 2008; 43). These submissions testify to the ineffaceable role of the personality and perception of the leaders in making choices on behalf of the state. Hence, the argument of the leadership personality model revolves around the fact that, given the same circumstances, leaders are likely to make different decisions and the explanation for this can be partly discovered in the differences in personality of the leaders. 
The model views personality as the "unique learning history and genetic antecedents or composition", as well as the manner in which the integrated complexes of life influence response to certain stimuli in the environment. It also represents in broad terms, the "individually unique, consistent pattern of behavioural and psychological attributes that endure over time and across situations" (Smith cited in Afinotan and Agagu, 2008:58). In other words, personality emphasis moves around the enduring qualities of the person, and as Breuning (2007) puts it, a focus on personality enhances prediction of the actions and reactions of leaders.

Spread on to the realm of foreign policy, Kolawole (1998) argues that it is the leaders of the state who define the form, content and context of the foreign policy of a state. Consequently, a holistic comprehension of the foreign policy of a state also demands a holistic understanding of the personality of the leaders of that State. The psychological state of mind, the idiosyncratic nature of the leader, the perceptions of life and in other words, the personality of the leaders must be examined, if one is to comprehend the rationale and dynamics of the various foreign policy decisions taken by leaders. Juliet Kaarbo, Jeffrey Lantis, and Ryan Beasley (2012) in their work "The Analysis of Foreign Policy in Comparative Perspective" emphatically gave the summary of the application of the leadership personality model in analysing foreign policy decisions of leaders when they opined that;

At the top of government sits a leader, or leaders, who have the authority to make foreign policy. Characteristics of leaders are generally more important when they have significant latitude in shaping policy and the situation is ambiguous, uncertain, or complex. Under these conditions, which occur frequently in foreign policy making, a leader's personality and beliefs may shape what the state does. Leaders' decisions may be shaped by their own personal history. Their childhood or early political experiences, for example, may have taught them that certain values and ways of handling problems are important. The revolutionary tendencies of the Chinese leader Mao Tse-tung, for example, might be traced back to when he was a child... Manmohan Singh is India's first Sikh prime minister, and holds a Ph.D. in political economy from Oxford University. His values and professional training have influenced his government's emphasis on economic development and trade policy. Since every leader's personal history is unique, one might expect each individual to draw on a particular set of beliefs, values, and experiences in coping with foreign policy issues.

However, the leadership personality model is not without criticism, Breuning noted that although the childhood experiences are crucial to forming the personality of leaders, however, "to use a person's early life for more than general tendencies, which may manifest themselves in many different ways in later years" may become problematic. He however acknowledges that, this does not necessarily render insights derived from a person's early life useless, it does not imply that biographies of individuals which fundamentally shape their personality is not significant but rather, it does imply that caution must be taken so as not to over-interpret the relevance of the personality to the detriment of other factors that shape the decision making process of the leaders (Breuning, 2007). Hence the leadership personality framework becomes suitable for our current problematic, as it seeks to interrogate the rationale behind Cameron's decision to subject a delicate foreign policy issue to a referendum of the masses who have little or no knowledge about the implications of their choice within the context and framework of international power politics.

\section{The European Union}

The European Union is a typical example of a regional bloc made of several European nations, with the main objective of uniting the region for socio-political cultural and economic advantages in international relations. The proposed idea of a former French foreign minister Robert Schuman of integrating Western Europe's coal and steel companies in 1950, became visible when on the $18^{\text {th }}$ of April 1951, the Treaty of Paris which established the European Coal and steel community was signed. Following this, on the $25^{\text {th }}$ of March 1957, the treaties of Rome, was signed by six European nations (Belgium, France, West Germany, Italy, Luxembourg and the Netherlands).

Hence, Beddoes' (2016) submission that, “the origins of today's EU lie in the ashes of post-war Europe. Reconciliation between France and Germany, urged by Winston Churchill in 1946, led to the creation of the six-member European Coal and Steel Community". The treaty established the European Economic Community and the European Atomic Energy Community. These treaties became the foundational stone for an integrated European committee of states (European Union, 2013; Wilkinson, 2016). By1967, the European community had been created and this community was joined by Britain in 1973 under the administration of Tory Prime Minister Edward Heath.

In February 1986, the Single European Act was signed, which was to create an inter-regional market, in which restriction on means of production and labour will be at minimal level. Following this, the Maastrict Treaty was 
signed on the $7^{\text {th }}$ February 1992 with the central objective of creating a single currency for the region that can compete with the dominance of the United States dollar in the international system. The Maastrict Treaty which came into force in 1993, led to the establishment of the European Union which was to further facilitate the integration of the region (European Union, 2013; Truman, 2015). The heart of the European Union revolves around attaining various socio-political, economic, and environmental benefits for her member states and her citizens. The union which consists of independent nations that voluntarily decides to pool part of their 'sovereignty' in order to derive socio-political, economic and strategic advantages from the strength and the benefits of size.

The pooling of sovereignty implies that "member States delegate some of their decision-making powers to the shared institutions they have created, so that decisions on specific matters of joint interest can be made democratically at European level" (European Union, 2014). Briney (2010) posits that, the Treaty of Maastricht which established the modern European Union identified five goals which was to unify European nations far beyond economic terms. Accordingly, these goals includes; strengthening the democratic government of participating nations, improving the overall efficiency of the nations, establishing an economic and financial unification, to developing the "Community social dimension" and to establish a security policy for member states. Briney further stated that, "the European Union's mission for today is to continue prosperity, freedom, communication and ease of travel and commerce for its citizens". Hence, the central objectives of the union are to promote peace, uphold the Union's values and the well-being of its peoples.

The objectives of the union can also be found in the Lisbon treaty which was signed in 2009 to include, but not limited to the following:

1. The promotion of peace and the well-being of the Union's citizens

2. promotion of an area of freedom, security and justice without internal frontiers

3. Ensure the realisation of sustainable development based on balanced economic growth and social justice

4. Promotion of a social market economy, that will be highly competitive and aiming at full employment and social progress, as well as the creation of a free single market

5. combating social exclusion and discrimination, and the promotion of social justice and protection, equality between women and men, solidarity between generations and protection of the rights of the child

6. The promotion of economic, social and territorial cohesion, and solidarity among Member States. (Borchardt, 2010).

The European Union has achieved much since it was established from the primordial beginning in the form of the European Economic Community. Foremost among its achievement is the inevitable fact that the union has been able to establish a common market for goods and services that spans the boundaries of 28 Europe countries, consequent upon this, the restriction on labour and other means of production is at minimal level with "over 500 million citizens free to move and settle where they wish". More so, the regional supranational body has succeeded in creating a single currency for the region and the currency known as the Euro has evolved to become one of the major world currencies in contemporary times.

In addition to this, the supranational body is also the "largest supplier of development and humanitarian aid programmes in the world" (European Union, 2013).Furthermore, the body has successfully set the standard of how a regional integrated body should function. In this regard it as become an example to other regional bodies across the globe. And the body is striving to unify Europe more than what is obtained in the present. It is tirelessly pooling efforts to combat the growing menace of terrorism, the unending issue of climate change and the quivering economic recession threatening most parts of the world today. In spite of the growing popularity and efficiency of the European Union in World socio-political, and economic affairs, and in addition to the rising advantages that the benefit of size bestow upon member nations, the quest for Brexit still surfaced in Britain.

\section{The Brexit Narrative}

As Beddoes (2016) posits, the origin of today's European Union lies in the ashes of the post war Europe, and in the reconciliation agenda of Germany and France. Wary Britain, interested in a strong bond with the Commonwealth and America, stood aside from the formation of the Union until Britain, became impressed by the continent's stronger economy, and eventually joined the Union in 1973. Ever since then there has always been one sentiment or the other regarding Britain's membership with the European comity of states. Hence, the call and question for Britain to leave or stay within the European community is not an entirely new phenomenon. But 
rather its story is deeply engraved in the trajectories of history, which dates back to the primordial period when Britain decided to join the European comity of states.

The first referendum which deliberated the case of "Brexit/stay" was held in 1975, in which $66 \%$ of voters voted for Britain to stay in the European Community (Truman, 2015). Truman revealed that the referendum of Prime Minister Harold Wilson was the last national referendum that deliberated Britain's stand with the European community. Sully (2016) noted that the possibility for referendum on sensitive issues were however denounced by subsequent administrations, especially under the government of Margaret Thatcher who conceived of such popular democratic vote on delicate foreign policy issues, as "being an instrument of 'demagogues and dictators'.

However, the question of referendum found its way back into a decisive and delicate foreign policy affair years after, under the administration of Prime Minister David Cameron, when he delivered a speech at the Bloomberg Conference on 23 January 2013. At the conference, Cameron stated: "I want the European Union to be a success. And I want a relationship between Britain and the EU that keeps us in it. Let me set out my vision for a new European Union, fit for the 21 st Century. It is built on five principles" he explained that the first principle is concerned with the issue of competitiveness, which also includes "cutting the total burden on business", the second principle argues for the flexibility of the union, the third principle argues that power must be able to flow reciprocally from Member States and back to the Member States, and not just away from them; the fourth principle he stated is concerned with democratic accountability; while the fifth principle focus on the fairness of the European Union to all and sundry (Brown, 2016).

Cameron gave his report for the necessity for a reform in the European Union treaty he asserted that the public feel that the European Union is deviating from the primordial objective of its existence, and that rather than jointly benefit Member States, the Union is merely appropriating resources to Brussels and dictating to other member states, which in his view restrains Britain from a national life of greatness. Following this, Cameron did commit himself with promises of ensuring favourable negotiations and then conducting a referendum on the membership of Britain in the European Union. Brown (2016) reveals that Cameron's promise was thus woven into his party manifesto and accordingly, as a result the Conservative party manifesto embrace that "It will be a fundamental principle of a future Conservative Government that membership of the European Union depends on the consent of the British people - and in recent years that consent has worn wafer-thin". Brown reveals that the party further argue that consequent upon their resolution, the party after the election, "will negotiate a new settlement for Britain in Europe, and then ask the British people whether they want to stay in the EU on this reformed basis or leave".

Hence upon victory in the May 2015 General election, Cameron was obliged to fulfil his own part of the bargain by delivering the promises of renegotiation with the European Union and also conducting a referendum on the issue. Consequently, while Cameron was engaging and mobilizing events and the political space for favourable negotiations with the European Union, the citizens, motivated by few elite camps were blowing the trumpet for the actualization of the referendum. And these developments was what led to the advent of political, individual and civil society groups committed to promotion of the referendum stance, hence the coinage "Bremain or Brexit"?(Brown, 2016).

Issuing from this development, Brown identified several camps that constitute the key significant players in the Brexit / Bremain narrative. For the Pro-Brexit camp, the Vote Leave camp, Leave EU, and Labour Leave constitute the major campaign groups that subscribe to the motion to leave the European Union. Brown explained the major argument of each of this groups in his work. Brown revealed that the Vote leave group was set up by Chief Matthew Elliott with the backing of business leaders, who are sceptical of Euro-Britain relations among others. He posits that the position of the Vote leave camp can be summarized in the following words;

Technological and economic forces are changing the world fast. EU institutions cannot cope. We have lost control of vital policies. This is damaging. We need a new relationship. What happens if we vote 'leave'? We should negotiate a new UK-EU deal based on free trade and friendly cooperation. We end the supremacy of EU law. We regain control. We stop sending $£ 350$ million every week to Brussels and instead spend it on our priorities, like the NHS and science research. We regain our seats on international institutions like the World Trade Organisation so we are a more influential force for free trade and international cooperation. A vote to 'leave' and a better, friendlier relationship with the EU is much safer than giving Brussels more power and money every year (Brown, 2016; 4)

On the other hand, the Leave.EU referendum campaign group which is led by Arron Banks and Richard Tice turned out to be the people's group, securing over 300,000 supporters from across the United Kingdom (Brown, 
2016). The rationale behind the Leave.EU referendum campaign and the central argument of the group is expressed thus;

Imagine having $£ 1,000$ more to spend each year. By leaving the EU, each household could be better off by this amount - through cheaper food bills, no membership fees, with the cost of regulations lifted, too. Imagine not having our laws dictated to us by Brussels. Instead, MPs would become accountable to the public and we would once again be able to make and decide on our own laws. Imagine how we could then regain control of important issues such as our borders. We could welcome the right talent from all over the world - adding to the country's already phenomenal cultural and economic strength (rather than having to accept all EU migrants regardless of skill level). Imagine having greater influence over our global trade, so that we can do our own deals with fast-growing Commonwealth countries and North America (without 27 other EU countries all arguing for their own special interests!). Imagine the sense of pride we would get from negotiating our own global trade deals; if Iceland can negotiate a free trade deal with China, then we most certainly can. It's time to be a bigger part of the world rather than a smaller part of Europe. We believe Britain could do so much better outside of the EU (Brown, 2016; 4)

The third group which is the labour leave is championed by Kate Hoey MP and Graham Stringer MP alongside with John Mills who is the Secretary. The purport of the group is to support and represent the majority of the labour party members who are willing to see a significant change in Euro-Britain relations and who do not believe that the reforms will bear benevolent fruits. In expressing the case of the group, Kate Hoey MP wrote:

The Labour Party is looking at radical policies to tackle the problems in our country. We need to take back real control from the unelected and unaccountable European Commission if we are to have a chance of implementing any of these. The votes of the Left cannot be taken for granted in this referendum: there is now strong Trade Unionists against the EU campaign, and around the country, grassroots campaigners are speaking out. Labour Leave may be in a minority within the PLP, but then so was support for Jeremy Corbyn. I have never felt so optimistic about our chances of winning the referendum. In the event of a Brexit, we can trade and co-operate with other European countries not involved with the EU, and reach out globally, particularly to the bloc of Commonwealth countries in Asia. We face a great opportunity if we leave. We can stop being Little Europeans and become Internationalists again (Brown, 2016; 4).

Just as the three significant Pro-Brexit groups were campaigning for their case of why Brexit is inevitable; the Pro-Euro groups also campaigned for the case of Britain to remain a part of the European Union. The main Pro-Euro groups as are the, Britain stronger in Europe, Britain Influence, The Senior European Experts Group, and the Labour In (Brown, 2016). The Britain stronger in Europe group argues that Britain is stronger, safer and better off in Europe than in isolation. Accordingly, "To vote to remain part of Europe is to vote for a stronger, better off, safer Britain...To vote to leave is to take a leap into the unknown, risking a weaker economy, the prospects of future generations and a loss of influence on the world stage" (Brown, 2016;6). The group which is led by Lord Stuart Rose is also supported by three former British Prime Ministers - John Major, Tony Blair and Gordon Brown.

The second Pro-Euro group is the British Influence group founded in 2012, by Peter Wilding alongside Danny Alexander, Kenneth Clarke and Peter Mandelson among others. The group argues that as the games are changing, Britain can only benefit "if we work with allies to reform the EU we can make even more of our membership. Britain must remain engaged and work within the EU for change. Taking the defeatist and self-defeating route would leave other countries to set the agenda in Europe and then impose it on us" (Brown, 2016; 6).

The third Pro-Euro group is the Labour In, which represents the view of the Labour party members who believe that Britain can become more successful and efficient by retaining its membership in the European Union. The Labour In group is championed by Alan Johnson with the leader of the party Jeremy Corbyn agreeing with the idea behind the formation of the group. Alan Johnson, summarized the inevitable need for Britain to retain its EU membership in succinct terms accordingly, he stated that the call for Britain to remain in EU is "about British businesses, businesses that rely on Europe for exports worth 227 billion pounds a year; and it's about Britain's global influence; in this increasingly interdependent world we can achieve more by working with Europe than we can alone" (Brown, 2016; 7). 
Another major Pro-Euro campaign group is the "Senior European Experts Group" the group consist of erstwhile prominent British diplomats and civil servants. The group is spurred on by the personality of people such as Lord John Kerr, Lord Robin Butler, Lord David Hannay, Sir Nigel Sheinwald, Sir Colin Budd among others and produces "authoritative briefings" for the British Influence group(Brown, 2016; 7).

These were the major groups that constituted the key significant players that campaigned for the Leave and Remain Chronicle's. Their views were succinctly sold out to the masses. Beddoes (2016) laments that the voters ahead of the election were confused by claims and counter claims made by each opposing side and were in need of plain facts on Britain's EU membership so they can make up their minds. Beddoes posits that's sad enough, plain facts were hard to find and justifiably so, because no one could tell precisely what will happen in the Post-Brexit Britain. Hence the plebiscite was conducted on the $23^{\text {rd }}$ of June 2016 amidst the insufficient facts and knowledge of the decisions to be made. Hence the majority voted in favour of the Pro-Brexit camp.

\section{Popular Democracy and the Brexit Account}

The international system in recent years; have witnessed the sporadic spread of democratic currents. With the wide spread of democratic principles, the argument of the populace having substantial influence in shaping decisions in each political system gained momentum. In reality however, not all decisions can be subjected to the inputs and influences of the masses, giving the fact that a large number of the mob are ignorant of the fact and consequences of certain decisions. However, the advocates of democracy failed to specify the nature of decisions which can be subjected to influences and inputs from the masses.

Sully (2016) believes that a country like Britain ought to be careful in throwing strategic decisions to the public; and one of such strategic decisions is the membership of the European union by the United Kingdom. Sully maintained that the United Kingdom is generally populated with individuals who are generally sceptical of the European Union, making popular democracy on issues concerning the European Union a risky and dicey endeavour. In view of the obvious fact that foreign policy decisions are strategic and delicate in nature, should such important decisions be thrown to the populace who have little or no idea of the consequences of such foreign policy manoeuvres? Sully explains that, when Britain joined the European Economic Community in 1973, there was no plebiscite to decide on such strategic foreign policy action.

Thus her entry into full membership of the EEC was at that time a matter of necessity for a country trotted by economic crisis. However, a few years after Britain signed membership agreement with the European comity of states, inflation rose steadily to around 30 percent. Whether or not this could be attributed to membership of the union however remained a moot point. Nevertheless, to the average Briton, Europe was bad news and stayed that way. Consequently, Labour Prime Minister Harold Wilson, decided to hold a referendum on Britain's proposed membership of the European community. Fortunately, the poll result favoured Britain remaining part of the European community. However, in the 2016 referendum which Cameron brought about, the majority voted for an end to Britain's membership of the European Union. The Brexiteers reasoned that membership of the European Union is a mockery of sovereignty, where the powers to decide on critical issues, connected with national border, trade and security among others, rests with the decisions made in Berlin and Brussels. Hence this development has allegedly led to the redundancy of Britain as a significant mega power in World Politics. The Brexiteers, thus long for a reassertion of British power on the world stage, and just like America become once again, a renowned player and a leading power in international politics. Thus the key to becoming great again would lie in Britain withdrawing her membership of the European Union and then regaining absolute sovereignty. With this, Britain will be free from all bonds, and can then act and relate with the outside world, independent of the dictates of other European states.

In the words of Witney, the Brexiteers claim that "indeed, quitting the EU will put the 'Great' back into Britain, allowing us to resume our historical vocation of a truly global power. Links with Commonwealth and Anglophone nations around the world will be renewed". In this view, unlimited connection can be built with the member states of the Commonwealth of Nations and with America and other regions and states that can help the actualization of Britain's interest. Hence, the majority of the masses re-echoed the desire for Britain to become great and a major force in the international system, and regain dominance as it was in former times. The invoking of history thus became the fundamental justification for majority of the masses, without concrete parameters for state survival afterwards. Perhaps this was what informed Witney's (2015) reflection that if Britain chooses to exit the European Union then they should be able to clarify the question; if Brexit, then Brexit to where?

Witney noted that, although the aspiration to return to "Greatness" by the British is a decent one, longed for by most nations of the world, "but this need not mean a retreat from the world to a "Little England". Witney argues 
that exiting the European Union leads Britain through an unknown fate which could either bring greatness or meagreness. The end result remains unknown but the greater part of the analysis at hand tends more towards a lonely and feeble Post-Brexit Britain. The Pro-Europe camp affirms this position, stating that although the drive for a Great Britain is undisputable, nevertheless the global endeavour of the United Kingdom can most truthfully be actualized if Britain combines the already existing reputation with the weight of the European Union.

With this strategy, knotted with skilful negotiations, Britain could become 'great' again. But judging by present reality, Witney posits that no European nation can by itself exercise real influence on the world stage in contemporary times. And unequivocally, "Britain no longer has the economic, diplomatic, or military weight to count for much in isolation...The road to shaping the twenty-first century world in accordance with British interests and values lies through leadership within Europe" (Witney, 2016). Thus it was within the ambits of a very limited view and enlightenment of the consequences of the Brexit/stay din, that the people were allowed to decide on a strategic issue that borders on the State's existence. This act which implications are widely unknown among the ranks of British voters, can be likened to giving a gun loaded with bullets to a child, who is ignorant of the implications of pulling a trigger. The child can either decide to pull or not to pull, acting only towards instinct void of all enlightenment. The outcome of such action is widely unknown, but danger lies in the possibility of the ignorant child pulling the trigger and causing irreparable harm. In such scenario, the ignorant child will not be the blameable culprit but the knowing adult who handed over such delicate weapon to the ignorant child.

Hence in the realm of strategic foreign policy decision making, the populace are no more than an ignorant child, handed over the responsibility of deciding the fate and future existence of the state. Should the masses act on instinct and sentiment void of all enlightened implications against pure logic and fact, the blameable culprit will not be the masses but on the contrary the leadership who granted that such delicate, strategic and decisive policy be placed in the hands of the masses. Here, the poverty of popular democracy reflects itself conspicuously, and is borne out in very bold relief. The average citizen knows little or nothing about issues of foreign dimensions, little or nothing is also known by them about the implications of their choices which reverberate beyond national borders. Therefore conducting a referendum on such an issue really amounts to putting a loaded gun in the hands of an ignorant child.

Experience all over the world has shown that, very often, democracy in the context of popular voting is a play ground for emotions and passions rather than of facts and logical reasoning. Democracy is therefore not likely in circumstances like this, to produce rational outcomes, in so far as it awards victory on the basis of percentages (Abati, 2016). And in Brexit, the difference between the Yes and No votes was just 4\%. But in every democracy, the rule is that the majority decides, irrespective of how narrow the margin of victory may be, and as it often happens, the game may turn out to be zero-sum. Thus as Reuben Abati has correctly observed:

... But should the economic and political destiny of a people be determined in such a formulaic manner? Brexit has left the United Kingdom in a more divided shape than it was before the referendum. The entire Country is in turmoil. The taste of Change doesn't seem quite so sweet any more, less than 72 hours after the vote. Young Britons may no longer be able to move freely across Europe, and experts have predicted rising costs and expectations and greater economic hardship. If Brexit stands, more than half of the population will be thrown into a winter of discontent, wondering why just about 1.3 million voters (17.4 million) for and (16.1 million) against should have been allowed to mislead a country. Many Britons will no longer be able to find jobs so easily across Europe. Hyperdemocracy has resulted in British discombobulation (Abati, 2016).

This is probably why Professor Bolaji Akinyemi (2016), Nigeria's former Minister of External Affairs, described the Brexit referendum as "a fantastically calamitous decision." In Akinyemi's opinion, a referendum on such an issue was neither necessary, nor called for. Democracy has since progressed from populism, to representative government, which is designed to ensure that complex issues are best deliberated upon by people who understand the consequences and the weightiness of the issues under discussion. This necessary fact did not seem to be evident in the Brexit decision.

\section{The Nexus between Theory and Practice}

Within the ambit of the Brexit narrative the blunder is framed around the leadership of the state. Beddoes (2016) opines that on a superficial look an answer to the why of Britain's Referendum is because Cameron promised one in the Conservative Party manifesto for the May 2015 election. But on a closer examination a deeper reason is to be found in the rise of British Euroscepticism. However it is important to note that the question of Britain's 
membership of the European comity of states is not a new phenomenon. It was an unending debate a few years after the United Kingdom signed to become a member of the European Union in 1973. In 1975, the Labour Prime Minister Harold Wilson conducted a referendum on Britain's membership of the European Community, and $66 \%$ of the voters voted that Britain should belong to the Community.

Truman (2015) had revealed that the referendum of Prime Minister Harold Wilson was the last national referendum that deliberated Britain's stand with the European community. The possibility for referendum on sensitive issues were however denounced by subsequent administrations especially under the administration of Margaret Thatcher who conceived of such popular franchise on delicate foreign policy matters as "being an instrument of 'demagogues and dictators' (Sully, 2016). This reveals that such issues of membership of the European organisation has never really died out, but has remained on the political front burner of the United Kingdom up till the formation of the European Union. However the approach of various leaders to the lingering issue of European Union membership greatly differs from one to the other.

The question of a referendum on decisive and delicate foreign policy affairs only found its way back years after, under the administration of Prime Minister David Cameron. The explanation for the promise of a referendum on such lingering strategic issues can thus be situated among other things, within the framework of the personality profile of Prime Minister David Cameron.

\section{David Cameron}

David Cameron was born on the 9th of October 1966 in England, a descendant of King William IV, it can be recalled that he is from a wealthy family and he received quality education. Catherine Mayer (2008) revealed that, Cameron is not necessarily a politically obsessive person, he does not take things to heart, if he fails to get what he wants, he would turn the other way and continue his life. "The thing about David is, he's not a political obsessive," says Tory chief executive Feldman. "If it all ended tomorrow, he'd pick himself up and start on something different." It's an admirable ability but one that seems unlikely to be tested in the near future". Julian Glover (2010) observed that Cameron's close associate reveals that, Cameron as a person loves to have people around him. Accordingly, he stated that "I suspect he doesn't like being alone. He is not given to sitting and pondering himself and his lot in life". Another friend puts it thus; Cameron is not holistically a visionary man, nor is he a man with a plan, but he always surrounds himself with men who do have plans. This suggest that Cameron may be easily subjected to influence and that he can easily be wooed into accepting decisions he would ordinarily not have accepted in order to keep people around him. Coupled with this fact, Catherine Mayer (2008) noted that one event that impelled Cameron, towards the direction of a more compassionate Conservatism, was the case of his first son, Ivan, who he had in 2002 and " who is severely disabled, and the brutal introduction this gave the family to state health care and social services. Ivan suffers from cerebral palsy and epilepsy and needs 24-hour care" this made Cameron a more compassionate conservative. As Cameron believes "a modern compassionate Conservatism is right for our times, right for our party — and right for our country". This is in tandem with the fact that Cameron loves to be with people and does not like to be alone, and the compassionate streams that his son's condition opened for him accentuated this aspect of his personality. To mix with people, to be a compassionate and conservative, and consequently become acceptable to people gradually formed the personality of acceptability for Cameron.

This was probably what informed Thomas Williamson (2013) observation when he noted that David Cameron as a leader, lacks conviction in his abilities, and as such he represents a "bad Prime Minister". He asserted that this is not because he has a wealthy background, or because he had quality education at Eton, on the contrary, it is because as a "Prime Minister he follows opinion rather than leading it". Cameron is described as an emollient and consensual personality, unlike the personality of Thatcher who was described as "abrasive, provocative, strident and confrontational" (Theakston, 2015).

His government changes policies frequently "as soon as it senses they are unpopular, such as over the pasty tax and cuts to school sport. Of course this is due to the fact that David Cameron, like Nick Clegg and Ed Miliband doesn't really believe in anything"(Williamson, 2013). Williamson further noted that, quality leadership requires the ability to do what they recognise as right and "risk losing the next election in order to enact those policies. Sometimes, however, voters credit them for their bravery and re-elect them". He gave the example of Margaret Thatcher, who refused to change course in her first term despite the pressure and confrontation and in spite of the fact that some of her policies were not welcomed by both her party and her opposition party, especially the economic policy. And in comparison to Thatcher, Williamson, noted that Tony Blair was more of a weak leader who spent his time in office doing what he perceived would make him acceptable and re-electable rather than doing what he recognised was the right thing to do (Williamson, 2013). 
Theakston (2015) reveals that Cameron gave his ministerial barons freedom and extensive independent to decide for him. He described Cameron as one who hands over strategic decisions to his cohort. Accordingly, his "relaxed, broad-brush and hands-off approach has been identified as a factor in the government's difficulties and problems with issues like the controversial big NHS reorganization, votes for prisoners and other policy U-turns and wobbles". Unlike his predecessor who paid attention to details, on strategic issues, Cameron, is merely surrounded by people who "outline the arguments on all sides of a question; he generally makes up his mind fairly quickly. Cameron has more of a broad-brush style even than Blair who could master details like a barrister when he needed to."(Theakston, 2015)

And reports reveal that Cameron's lack of attention to details sometimes disturbs his aides. Inferring from the various characteristics and descriptions of the personality of Cameron, it is unequivocal that the Prime Minister is people centred, emollient and consensual, and also one, who is fond of subjecting critical and strategic decisions to his cohort, who are then to provide the arguments on all side of the question. Also he is described as one who doesn't pay attention to details. These characteristics of him are undoubtedly part of the various elements that shaped his orientation and his acquiescence's to subject a critical and strategic decision to a referendum. His promise of a referendum reveals the lack of attention to details on strategic thinking and long-time analysis of decisions. Flowing from this the leadership personality model is valid in establishing a connection between the personality of a leader and the various actions, inactions and decisions of the leader.

\section{Plausible Consequences of Brexit}

Nicky Witney (2015) while examining the foreign policy consequences of Brexit, expressed that a vote to leave the European Union would have several consequences on the United Kingdom as well as on the European Union. Witney explained that, an exit from the European Union is a major foreign policy decision that holds severe consequences, dangerous for both Britain and the rest of Europe. Witney posits that currently, the United Kingdom is a major player in the global trade, "trading where it likes around the globe - and does so on better terms from within the world's biggest trade bloc".

The configuration of trade in contemporary times is such that challenges the existing domination of the West, with the rise of emerging economies providing alternatives to states across the globe. Witney (2015) argues that the World Trade Organization for example is "increasingly deadlocked - resulting in a global race to substitute a cat's cradle of bilateral, regional, and plurilateral arrangements". Hence it is becoming more difficult for states to independently navigate their ways through the murky waters of this sophisticated international trade arrangement and this has made regional bloc a force to reckon with in terms of Trade.

Although the European Union faces great criticism by its advocates, it nevertheless stands as a huge success and as an economic super power before the rest of the world. Hence Witney's argument that anticipating that Britain will "forge more favourable economic relations with the wider world by negotiating on its own is a triumph of hope over the reality that, when it comes to global trade, size matters".

Furthermore, the vote to exit the bloc may result in an isolated Britain whereby the calculation that an exit policy will deepen bonds with the Commonwealth and other partners outside Europe may become unrealistic. Witney (2015) opines that the fact remains that majority of the commonwealth and partners outside Europe are either indifferent, or want Britain to retain its membership in the European Union. In addition, the legacy of Britain to leave a major regional bloc may strengthen the resolve of some member states of Commonwealth that are in one way or the other disgruntled with the Commonwealth to leave the group of nations. This will consequently, narrow the numbers of trusted trade partners of the isolated Britain.

Moreover, the hope of getting advantageous deal with the commonwealth at the expense of the European Union may be dwarfed by the fact that the members of the commonwealth of states are also seeking advantageous deals, and are likely to drop Britain when the deals becomes unfavourable in comparison what they access with other states or regional bloc. Already, some of the member states of the common wealth are deepening trade relationship with France, Japan, and China at the expenses of the United Kingdom (Witney, 2015).

Alongside this, the legacy of Britain may also snowball into the domestic politics of nations, and regional politics among states, as domestic separatist groups and states covertly contemplating secession or excision can use the Brexit narrative as reference point for their cases. Consequently, the Brexit vote is likely to stimulate Scotland's bid to withdraw from the United Kingdom and become an independent entity that can relate with the European Union directly outside of the United Kingdom. On the other hand, states are likely to find readymade justification for pulling out of regional blocs using Brexit as a reference point. 
The German finance ministry has warned that a Brexit vote might induce France, Netherlands, Austria, Finland and Hungary to "follow Britain out of the European Union in a rash of anti-Brussels rebellions" (Squires, 2016). This might thus lead to an era of increased pulling out of states from regional blocs. Consequent upon which on the long run, the growing unity and strength derived from regional integration will no longer be attainable, and discord among regions may be on the rise. The signs are gathering momentum as Le Pen, the leader of France's far-right National Front set the tone for her presidential campaign with a promise to hold a nationwide referendum if elected as French president in the coming election. The far-right candidate for the 2017 April-May election in France pledged to back the "France of the forgotten, the abandoned and the voiceless" similar to the rationale behind the Brexit narrative (Sotto, 2016).

The Pro-Brexit camp often argue that, British defence and security interest will be well served if the United Kingdom becomes free from the variegated entanglement policies that dwarf the capability of the United Kingdom on the world stage. They often invoke history and historicise that, during the period of the cold war; Britain was a major force to reckon with, as it was the number one ally of the United States in the NATO bloc. Hence, becoming free from the European shackles will provide impetus for Britain to become a viable player in NATO and thus a significant force in the world (Witney, 2015).

However, scholars have observed that what is crucial to every state in the international system is the actualization of strategic interest defined as national interest. The United States, with a strategic interest of retaining the status of a global power aims at consolidating power beyond the confines of NATO. In a bid to actualize her strategic interest of retaining the status of a global power Washington will prefer that Britain remains in the European Union and pool efforts with other members of the European Union to ensure that they are able to check Moscow's expansionist tendencies. Consequently, the hope of forming a formidable alliance with United States and deepening relationship with NATO may become utopian. United States aims at maintaining the status of a global power and in doing so, needs the cooperation of the European Union to effectively contain Russian expansionist moves. Britain's decision to leave the Union therefore may expose Britain to stand alone with little support from NATO and Washington. Obama had stated that the United States would have preferred Britain to remain a committed and leading member state of the European Union (Witney, 2015).

\section{Concluding Remarks}

The Brexit referendum has generated worldwide interest by scholars and analysts across the globe, not only because of its immediate consequences, but more on account of the background to the formation of the EU, wherein lies the socio-political and strategic calculations behind the union now being put at risk by Britain's decision to exit. Many consider it an unfortunate decision because as Bolaji Akinyemi has pointed out, not only Great Britain, but also the European Union and indeed Africa will be hurt by it. Akinyemi (2016) had also argued that:

The whole idea of the European Union was designed to address the fact that two countries had dragged the whole world to war twice in this century- the first world war and the second world war... So the thinkers in Europe came to the conclusion that the only way to prevent France and Germany from going to war again, was to bring the two countries into a cooperative prosperity circle, and then get other European countries to join them. That is the foundation on which the concept of the European Union was established.

This is the very framework which, from a more global perspective the Brexit vote now seems to endanger, and unless the EU acts swiftly and decisively, this may have a domino effect across not only the United Kingdom but also the rest of Europe and indeed Africa and the Commonwealth of Nations. There is no gainsaying the fact that Britain is an important country with tremendous influence across the globe. Recklessness in foreign policy is perhaps the last thing the world would expect from the leader of the commonwealth. Whether or not there will be yet another referendum to correct what now seems to be a foreign policy blunder remains to be seen. In the meantime however if anything seems certain, it is that by the Brexit decision, Britain is obviously taking Europe back a couple of steps.

\section{References}

Abati, R. (2016, June 26). The Brexit Nightmare. Lagos: The Guardian Newspapers.

Afinotan, L. A., \& Agagu, A. A. (2008). Leadership Personality Model as a Tool of Political Analysis. In D. Kolawole (Ed.), The Nigeria Journal of the Social Sciences; The Faculty of the social sciences (Vol. 4, No. 2, 42-61.). University of Ado-Ekiti, Nigeria. 
Akinyemi, B. (2016, June 26). Blame Foreign Policy Recklessness for Brexit. Lagos: The Guardian Newspapers.

Asian Development Bank. (2013). Regional Cooperation and Integration in a Changing World. Retrieved from http://www.adb.org/sites/default/files/publication/30224/regional-cooperation-changing-world.pdf

Beddoes, Z. M. (2016). The Brexit briefs our guide to Britain's EU referendum. Retrieved from https://www.economist.com/sites/default/files/EconomistBrexitBriefsdf16.p

Biography.com Editors. (2016, August 18). David Cameron Biography. Retrieved from http://www.biography.com/people/david-cameron-39203\#synopsis

Borchardt, K. (2010). The ABC of European Union law. Retrieved from http://europa.eu/documentation/legislation/pdf/oa8107147_en.pdf

Breuning, M. (2007). Foreign Policy Analysis: A Comparative Introduction. NewYork: Palgrave Macmillan. https://doi.org/10.1057/9780230609242

Briney, A. (2010). A The European Union: A History and Overview. Retrieved from http://hoeyatbadger.weebly.com/uploads/5/3/7/2/53727829/european_union_reading.pdf

Brown, T. (2015). Brexit: The Leave Narrative. Retrieved from http://www.iiea.com/ftp/Publications/2015/BrexitThe\%20Leave\%20Narrative.pdf

European Union. (2013). The European Union explained; Your guide to the EU institutions. Retrieved from http://www.gr2014parliament.eu/Portals/6/PDFFILES/NA0113090ENC_002.pdf

Glover, J. (2010, April 25). David Cameron profile: Calm, confident and a pragmatist. But where would he lead Britain?. The Guardan. Retrieved from http://www.theguardian.com/politics/2010/apr/25/david-cameron-profile

Kaarbo, J., Lantis, J., \& Beasley, R. (2012). The Analysis of Foreign Policy in Comparative Perspective. Retrieved from http://www.fb03.uni-frankfurt.de/45431016/Beasley-et-al-2012---Foreign-Policy-in-Comparative-Perspecti ve---Ch-1.pdf

Kolawole, D. (1998). Personality and Foreign Policy: An Analysis of the Idiosyncratic Attributes of Selected Nigerian Foreign Ministers. In D. Kolawole (Ed.), Issues in Nigerian Government and Politics. Ibadan: Dekaal Publishers.

Mayer. C. (2008, September 11). David Cameron: UK's Next Leader?. Retrieved from http://content.time.com/time/world/article/0,8599,1840461,00.html

Omotosho, F. (2007). The Nature and Relevance of the Behavioral Revolution in Political Science. In F. Omotosho (Ed.), Readings in Political Behavior. Ibadan: University of Ado-Ekiti Press.

Peters-Berries, C. (2010). Regional Integration in Southern Africa - A Guidebook. Germany: Capacity Building International.

Pettinger, T. (2011). David Cameron Biography. Retrieved from http://www.biographyonline.net/politicians/uk/david-cameron.html

Quora. (2014). Why did David Cameron call for two very high-risk referendums on Scotland and UK membership in the EU? https://www.quora.com/Why-did-David-Cameron-call-for-two-very-high-risk-referendums-on-Scotland-an d-UK-membership-in-the-EU

Sotto, P. (2016). Le Pen promises French referendum on EU if elected president. Retrieved from http://www.usnews.com/news/business/articles/2016-09-03/le-pen-promises-french-referendum-on-eu-if-el ected-president

Squires, N. (2016). More countries could follow UK out of the EU, says German finance ministry, as European leaders warn radical reform is needed. Retrieved from http://www.telegraph.co.uk/news/2016/06/25/european-leaders-fear-brexit-vote-could-herald-eu-collapse-u nles/

Sully, M. (2016). The Brexit Drama - final curtain or prelude. Retrieved from http://oegfe.at/wordpress/wp-content/uploads/2016/06/OEGfE_Policy_Brief-2016.18.pdf

Trueman, C. N. (2015). A History of the European Union and Great Britain. Retrieved from 
http://www.historylearningsite.co.uk/british-politics/a-history-of-the-european-union-and-great-britain/

Wilkinson, M. (2016, June 22). What is the EU, why was it created and when was it formed?. The Telegraph. Retrieved from http://www.telegraph.co.uk/news/2016/06/20/what-is-the-eu-why-was-it-created-and-when-was-it-formed1

Williamson, T. (2013, August 9). Why David Cameron Is a Bad Prime Minister. Retrieved from http://www.shoutoutuk.org/2013/08/09/why-david-cameron-is-a-bad-prime-minister/

Witney, N. (2015). Brexit To Nowhere: The Foreign Policy Consequences of 'Out'. Retrieved from http://www.ecfr.eu/page/-/FP_Brexit_1141.pdf

\section{Copyrights}

Copyright for this article is retained by the author(s), with first publication rights granted to the journal.

This is an open-access article distributed under the terms and conditions of the Creative Commons Attribution license (http://creativecommons.org/licenses/by/4.0/). 